Provided for non-commercial research and educational use only. Not for reproduction or distribution or commercial use.

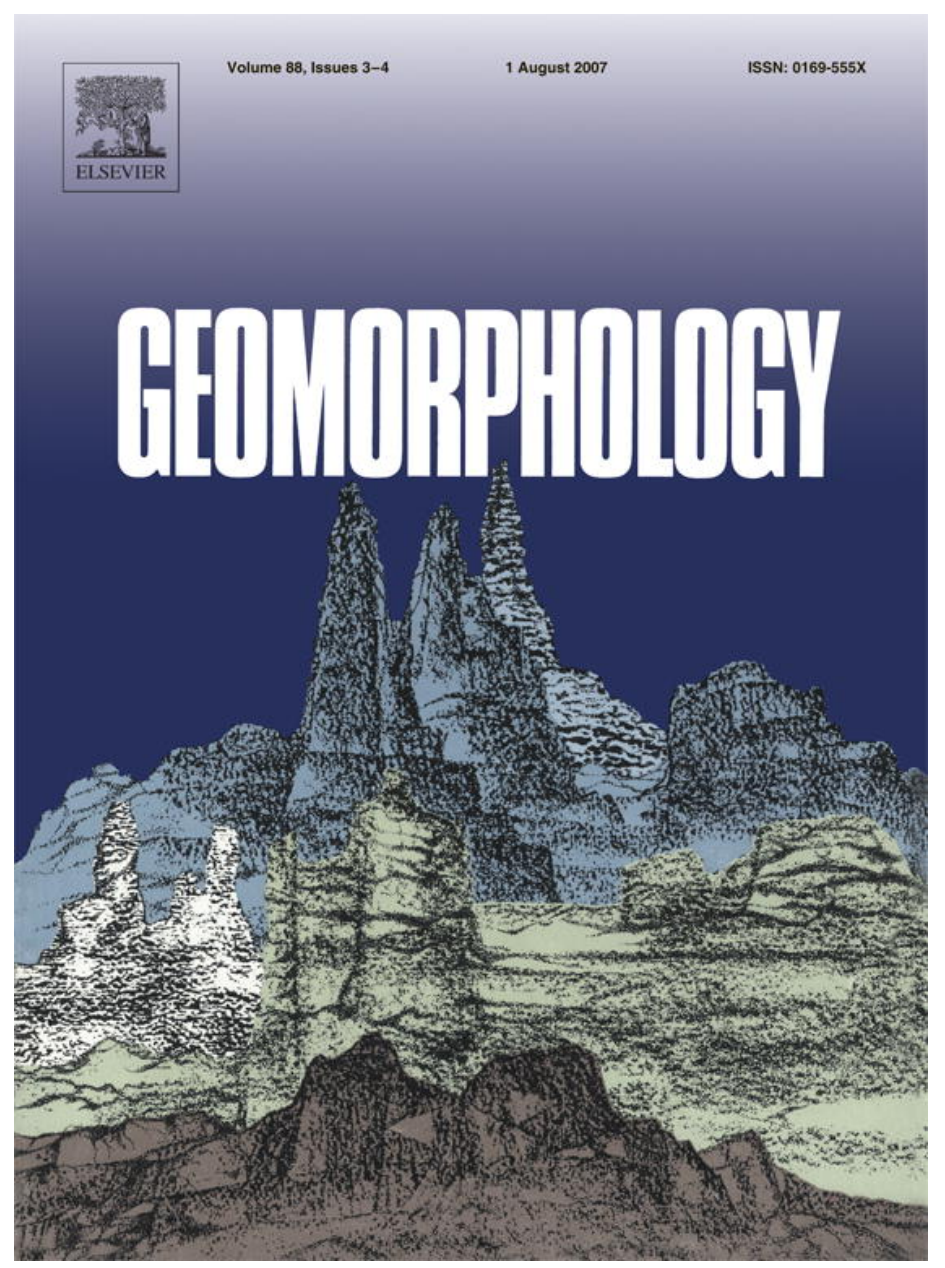

This article was originally published in a journal published by Elsevier, and the attached copy is provided by Elsevier for the author's benefit and for the benefit of the author's institution, for non-commercial research and educational use including without limitation use in instruction at your institution, sending it to specific colleagues that you know, and providing a copy to your institution's administrator.

All other uses, reproduction and distribution, including without limitation commercial reprints, selling or licensing copies or access,

or posting on open internet sites, your personal or institution's website or repository, are prohibited. For exceptions, permission may be sought for such use through Elsevier's permissions site at: 


\title{
Geological controls on Pleistocene glaciation and cirque form in Greece
}

\author{
P.D. Hughes ${ }^{\text {a,* }}$, P.L. Gibbard ${ }^{\mathrm{b}}$, J.C. Woodward ${ }^{\mathrm{a}}$

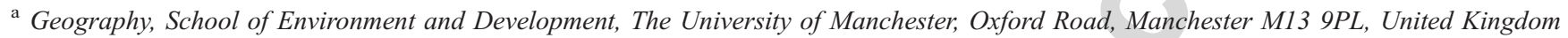 \\ ${ }^{\mathrm{b}}$ Cambridge Quaternary, Department of Geography, University of Cambridge, Downing Place, Cambridge CB2 3EN, United Kingdom
}

Received 4 April 2006; received in revised form 16 November 2006; accepted 16 November 2006

Available online 8 January 2007

\begin{abstract}
Limestone and ophiolite rocks are common across the eastern Mediterranean and many of the highest mountains are formed in these rock types. In northwest Greece, Pleistocene glacial erosion was much more effective on limestone terrain where pronounced glacial incision and subglacial glacio-karst processes produced locally-complex topography. This enabled Pleistocene glaciers to form on a range of slope orientations in contrast to ophiolite terrains, where glaciers were strongly controlled by aspect. On limestone terrains, the largest ice masses formed on south-facing slopes, whereas in neighbouring higher mountains formed in ophiolite, glaciers were much more restricted and predominantly formed on north- and east-facing slopes.
\end{abstract}

(C) 2006 Elsevier B.V. All rights reserved.

Keywords: Greece; Glaciation; Limestone; Ophiolite; Cirques

\section{Introduction}

The Pindus Mountains of Greece represent part of the Alpine-Himalayan orogenic system and formed as a consequence of collision between the African and Eurasian plates (King et al., 1997). The highest mountains are dominated by limestone and ophiolite rocks with flysch rocks commonly preserved in the foothills (Fig. 1). The limestone rocks formed during the Mesozoic within basins of the Palaeotethys Sea whilst Jurassic ophiolites were emplaced at a westwarddipping subduction-zone (Jones and Robertson, 1997; King et al., 1997). Uplift throughout the Palaeogene and Neogene produced mountains sufficiently high to be

\footnotetext{
* Corresponding author.

E-mail address: philip.hughes@manchester.ac.uk (P.D. Hughes).
}

extensively glaciated during Pleistocene cold stages (Hughes et al., 2006a,b,c,in press).

This paper presents evidence of glacier distributions and landform development on neighbouring ophiolite and limestone mountains in the northern Pindus Mountains and examines the role of rock type in glacier initiation, glacier-climate interaction and geomorphological impact. As limestone and ophiolite rocks commonly form the highest mountains in the Eastern Mediterranean (Robertson and Shallo, 2000), it is important to understand the influence of bedrock lithology and structure on any regional variability in the Pleistocene glacial record.

\section{Study area}

The Pindus Mountains of Greece contain many summits over 2000 m a.s.l. (Sfikas, 1979) This paper 


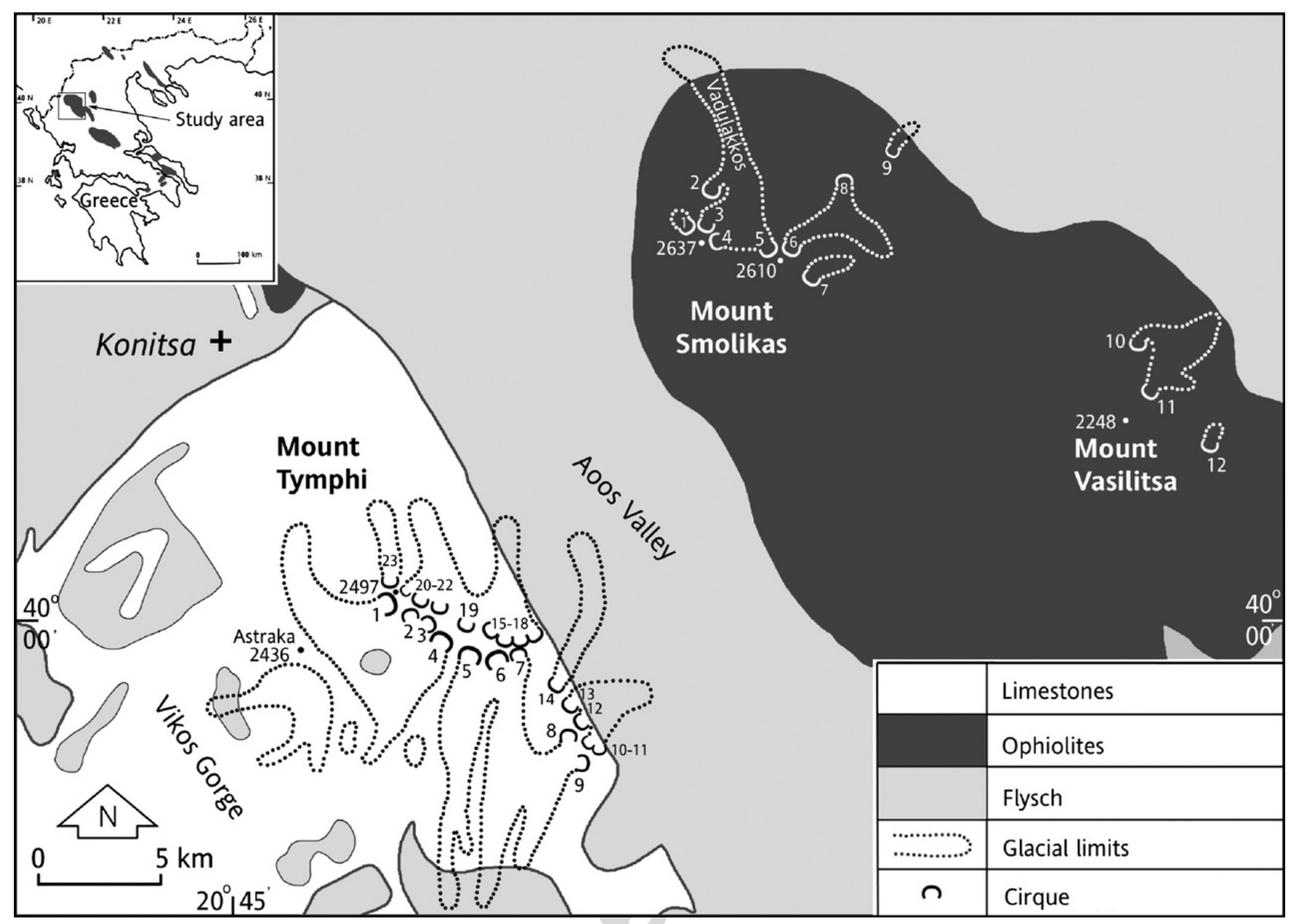

Fig. 1. Geological and location map of the northern Pindus Mountains, Greece. Cirques are numbered (see Table 2 for cirque names and form data) and maximum Pleistocene glacial limits are marked.

focuses on the neighbouring mountains of Mounts Tymphi (2497 m a.s.1.) [limestone], Smolikas (2632 $\mathrm{m}$ a. s.1.) [ophiolite] and Vasilitsa (2248 $\mathrm{m}$ a.s.1.) [ophiolite] in the northern Pindus. These mountains surround the lower and middle reaches of the Aoos river basin (Figs. 1 and 2).

The limestones of Mount Tymphi are mainly Palaeocene and Upper Eocene in age. However, older Upper Jurassic/Senonian limestones and dolomites are also exposed on the cliffs of the northern escarpments of the highest peaks. Upper Eocene/Oligocene flysch is largely restricted to the lower mountain slopes and was mostly situated outside the main areas of glacier erosion (IGME, 1970) (Fig. 1).

The ophiolites of Mount Smolikas and Vasilitsa are part of the Pindus ophiolite complex (Jones and Robertson, 1997) and comprise mainly harzburgites, some dunites and are traversed by pyroxinite and gabbro veins. Jurassic shists and limestones are also present locally, at the overthrust nappe of the ophiolitic complex (IGME, 1987). The Pindus ophiolite complex is part of a nappe which is tectonically overthrust onto the Eocene flysch of the Pindus Zone.

\section{Glacial history}

Glaciation is recorded from three separate glacial cycles in Greece (Hughes et al., 2006a) (Fig. 2). The oldest and most extensive recorded glacial deposits contain secondary calcite cements that have been dated by Uranium-series dating to $>350,000$ years BP. These deposits have been attributed to the Skamnellian Stage, which is equivalent to the Elsterian Stage of Northern Europe and MIS 12. A second glaciation took place during the Vlasian Stage, which equates to the later Saalian of northern Europe and MIS 6. The most recent phase of glaciation occurred during the last cold stage $($ Tymphian Stage $=$ Weichselian Stage $=$ MIS 5d-2).

\section{Methods}

The palaeo-glacier dataset from Greece (Hughes et al., $2006 a, b, c$, in press) was examined to test whether there are any significant differences in glacier characteristics 

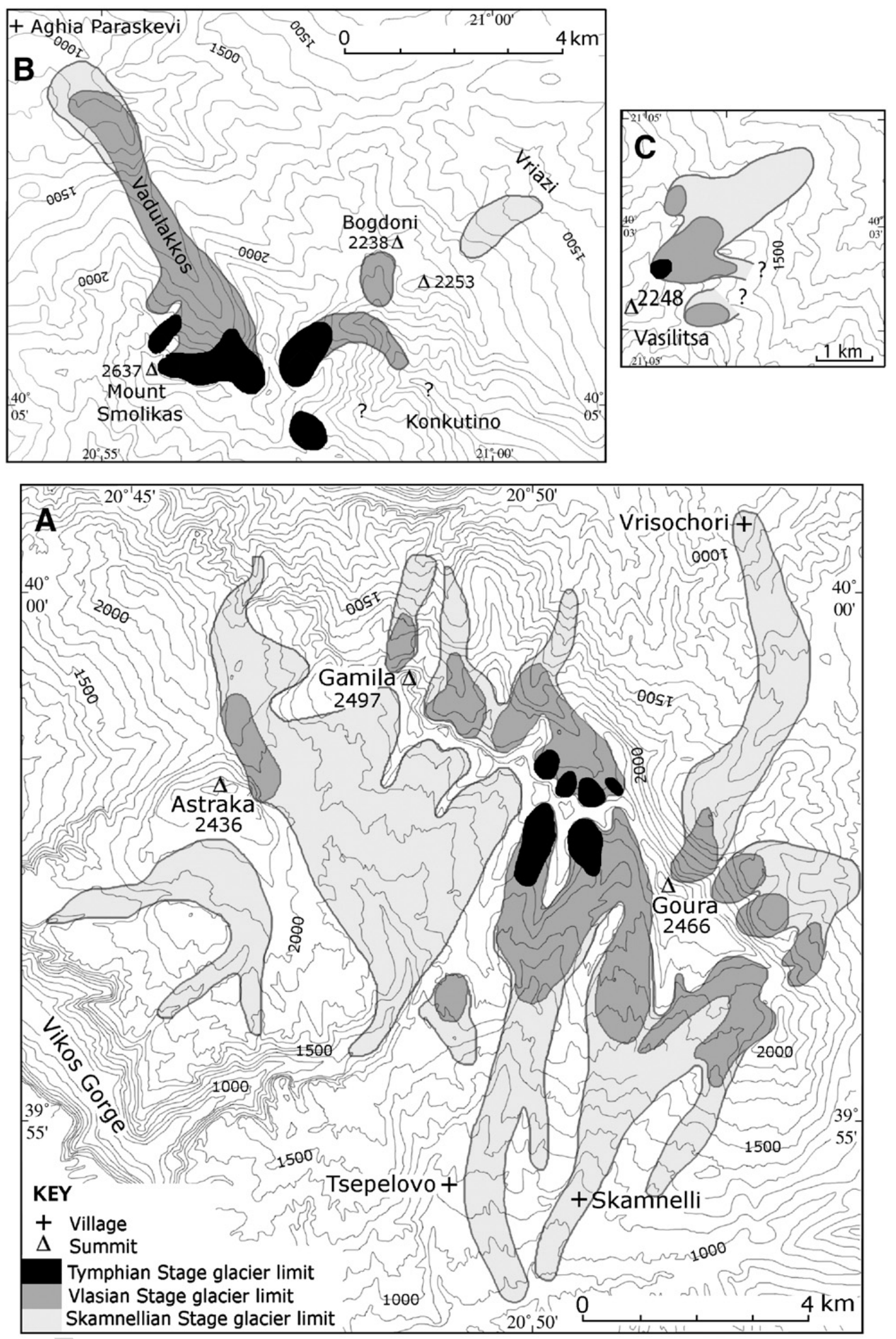

Fig. 2. Topographic map of Mount Tymphi (A), Mount Smolikas (B) and Mount Vasilitsa (C) showing glacier extent and distribution during different Pleistocene cold stages.

between ophiolite and limestone areas. Glaciers were reconstructed following methods outlined in Hughes et al. (in press) and glacier characteristics were compared between mountains formed in ophiolite (Mount Smolikas and Mount Vasilitsa) and mountains formed in limestone (Mount Tymphi). 
Cirque distribution and form were analysed using 1:50,000 Soviet topographic maps (contoured at $20 \mathrm{~m}$ intervals). The details of Pindus cirque morphometry were described following the techniques outlined in Evans (1969), Bennett (1990), and employed in other Mediterranean mountains such as the Pyrenees by García-Ruiz et al. (2000) and the Alpes Maritimes by Federici and Spagnolo (2004). They are outlined briefly below and illustrated in Fig. 3.

The length-width $(L / W)$ parameter represents the ratio of cirque length to cirque width and is a measure of cirque elongation. The greater the value the more elongated a cirque. The width-amplitude (W/A) parameter represents the ratio of cirque width to cirque amplitude (height between the lip of the cirque to the top of the cirque backwall) and is a measure of cirque incision. Lower values indicate greater incision.

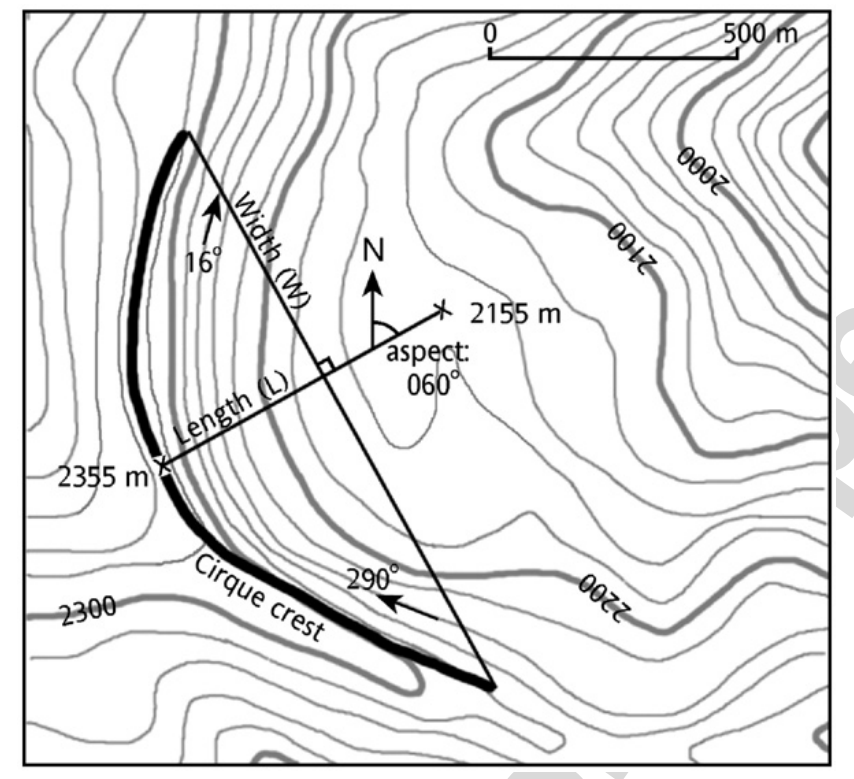

Fig. 3. Measurement of width, length, amplitude and aspect variables for the Moasa 3 cirque on Mount Smolikas (cirque number 7 in Fig. 1, and Table 2). Cirque width $(W)$ represents the distance across valley from opposite cirque ends $(1250 \mathrm{~m})$. Cirque length $(L)$ represents the distance from the cirque backwall to the cirque lip along a line drawn perpendicular to the cirque width $(625 \mathrm{~m})$. The amplitude $(A)$ of the cirque is the difference between the altitudes of the cirque backwall apex and the cirque lip along the cirque length transect $(2355 \mathrm{~m}-$ $2155 \mathrm{~m}=200 \mathrm{~m}$ ). The orientation of this line facing outwards from the cirque backwall represents the cirque orientation. The range in azimuth of the longest contour - in this example $290^{\circ}$ to $16^{\circ}$ can be used to calculate plan closure, $\left(360^{\circ}-290^{\circ}\right)+16^{\circ}=86$. Profile closure is calculated subtracting the maximum headwall gradient from the minimum floor gradient, (backwall: $100 \mathrm{~m}$ fall in $100 \mathrm{~m}$ distance) $45^{\circ}$-(floor: $10 \mathrm{~m}$ fall in $200 \mathrm{~m}$ ) $2.86^{\circ}=42.14^{\circ}$. Profile measurements can be determined from contour spacing on detailed maps or can be measured in the field using a level. Adapted from Bennett (1990) and Evans and Cox (1995).
Table 1

Glacier characteristics during different glaciations

\begin{tabular}{|c|c|c|c|c|}
\hline & Lithology & $\begin{array}{l}\text { Tymphian } \\
\text { stage MIS } \\
5 \mathrm{~d}-2\end{array}$ & $\begin{array}{l}\text { Vlasian } \\
\text { stage MIS } \\
6\end{array}$ & $\begin{array}{l}\text { Skamnellian } \\
\text { stage MIS } 12\end{array}$ \\
\hline \multirow[t]{8}{*}{$\begin{array}{l}\text { Mount } \\
\text { Tymphi }\end{array}$} & \multirow[t]{8}{*}{ Limestone } & $\begin{array}{l}\text { Glacier } \\
\text { area: } 3.9 \mathrm{~km}^{2}\end{array}$ & $\begin{array}{l}\text { Glacier } \\
\text { area: } \\
21.3 \mathrm{~km}^{2}\end{array}$ & $\begin{array}{l}\text { Glacier } \\
\text { area: } \\
59.2 \mathrm{~km}^{2}\end{array}$ \\
\hline & & Mean & Mean & Mean \\
\hline & & ELA: & ELA: & ELA: \\
\hline & & $2174 \mathrm{~m}$ & $1862 \mathrm{~m}$ & $1741 \mathrm{~m}$ \\
\hline & & $\begin{array}{l}\text { Glacier } \\
\text { orientation }\end{array}$ & $\begin{array}{l}\text { Glacier } \\
\text { orientation }\end{array}$ & $\begin{array}{l}\text { Glacier } \\
\text { orientation }\end{array}$ \\
\hline & & N: $67 \%$ & N: 38\%; & N: $33 \% *$ \\
\hline & & $\mathrm{S}: 33 \% *$ & S: 31\%; & S: $53 \%$ \\
\hline & & & E: $23 \% *$; & East: $7 \%$ \\
\hline \multirow{10}{*}{$\begin{array}{l}\text { Mount } \\
\text { Smolikas }\end{array}$} & \multirow{10}{*}{ Ophiolite } & Glacier & $\begin{array}{l}\text { W: } 8 \% \\
\text { Glacier }\end{array}$ & $\begin{array}{l}\text { West: } 1 \% \\
\text { Glacier }\end{array}$ \\
\hline & & area: & area: & area: \\
\hline & & $2.55 \mathrm{~km}^{2}$ & $6.6 \mathrm{~km}^{2}$ & $>8.1 \mathrm{~km}^{2}$ \\
\hline & & Mean & Mean & Mean \\
\hline & & ELA: & ELA: & ELA: \\
\hline & & $2241 \mathrm{~m}$ & 1997 m & $1680 \mathrm{~m}$ \\
\hline & & $\begin{array}{l}\text { Glacier } \\
\text { orientation }\end{array}$ & $\begin{array}{l}\text { Glacier } \\
\text { orientation }\end{array}$ & $\begin{array}{l}\text { Glacier } \\
\text { orientation }\end{array}$ \\
\hline & & $\mathrm{N}: 83 \% *$ & $\mathrm{~N}: 50 \% *$ & $\mathrm{~N}: 40 \%$ \\
\hline & & E: $17 \%$ & S: $25 \%$ & S: 20\%; \\
\hline & & & E: $25 \%$ & E: $40 \% *$ \\
\hline \multirow{7}{*}{$\begin{array}{l}\text { Mount } \\
\text { Vasilitsa }\end{array}$} & \multirow[t]{7}{*}{ Ophiolite } & Glacier area: & Glacier area: & Glacier \\
\hline & & $0.12 \mathrm{~km}^{2}$ & $1.2 \mathrm{~km}^{2}$ & $\begin{array}{l}\text { area: } \\
>3.4 \mathrm{~km}^{2}\end{array}$ \\
\hline & & Mean & Mean & Mean \\
\hline & & ELA: & ELA: & ELA: \\
\hline & & $2050 \mathrm{~m}$ & $1865 \mathrm{~m}$ & $1675 \mathrm{~km}$ \\
\hline & & $\begin{array}{l}\text { Glacier } \\
\text { orientation }\end{array}$ & $\begin{array}{l}\text { Glacier } \\
\text { orientation }\end{array}$ & $\begin{array}{l}\text { Glacier } \\
\text { orientation }\end{array}$ \\
\hline & & E: $100 \% *$ & $\begin{array}{l}\text { N: } 50 \% * \\
\text { E: } 50 \% *\end{array}$ & E: $100 \% *$ \\
\hline
\end{tabular}

Glacier orientation was divided into 4 directions: North $=315-045^{\circ}$; South $=135-225^{\circ} ;$ East $=045^{\circ}-135^{\circ} ;$ West $=225-315^{\circ}$. Orientations are derived perpendicular to the ELA, and may be different from the orientation of the source cirque. Glacier areas for Mount Smolikas and Mount Vasilitsa during the Skamnellian Stage are minimum estimates because of the fragmentary sedimentary record. MIS: Marine Isotope Stage, ELA: equilibrium line altitude.

* = lowest glacier orientation.

Since cirques are essentially concave forms their development is best measured in terms of their concavity or indentation (closure) in both profile (vertical section) and plan (horizontal section) (Bennett, 1990). Plan closure is the range in azimuth of the longest contour. A plan closure less than $90^{\circ}$ indicates that the cirque is only a shallow indentation in the mountainside while one in excess of $180^{\circ}$ indicates that it is closed on more than three sides. Profile closure is defined as the difference between the maximum headwall gradient minus the minimum floor gradient. Higher values indicate greater 

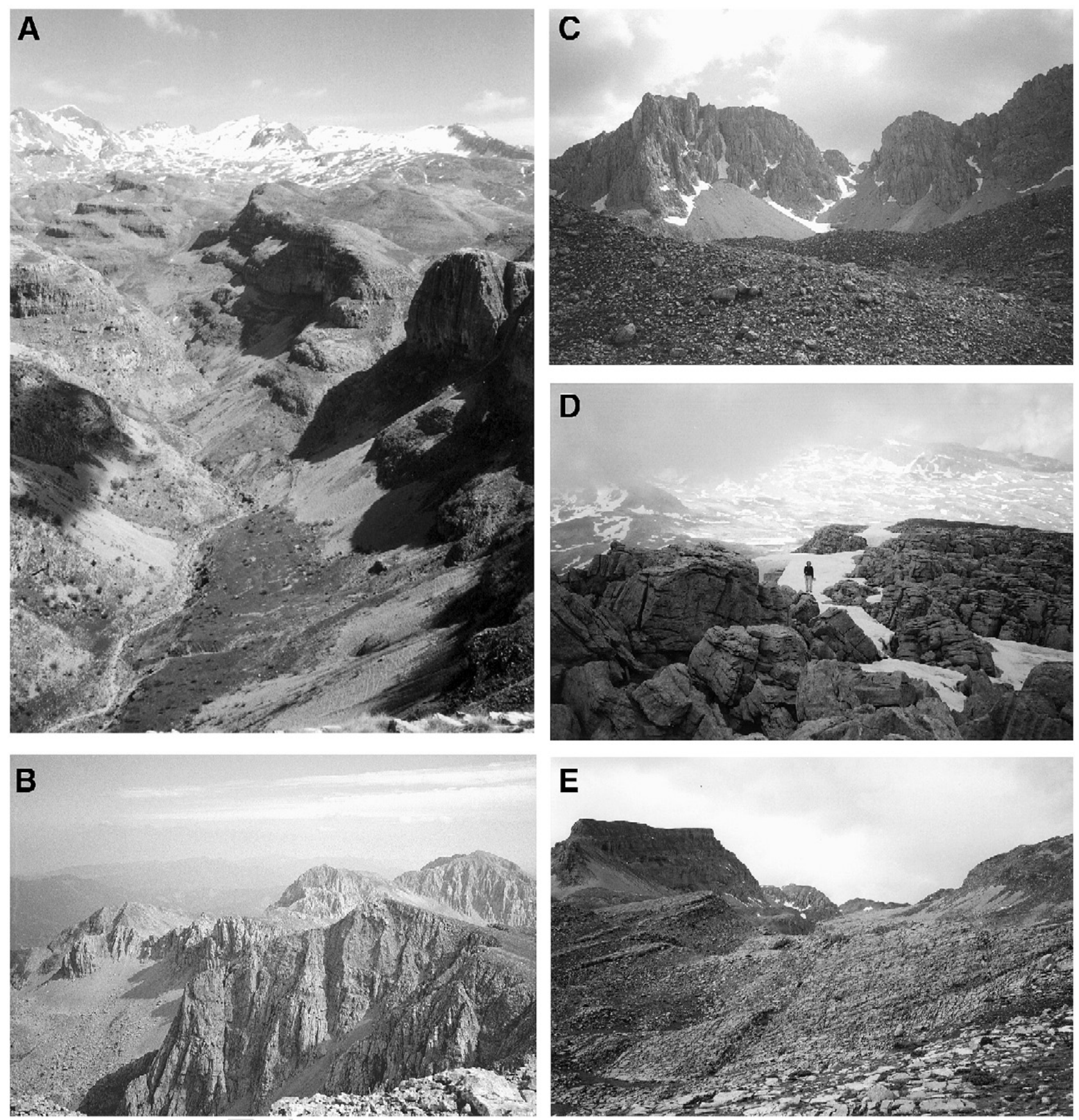

Fig. 4. A: Glaciated southern slopes of Mount Tymphi. This photograph is looking northeastwards up the Megas Laccos Gorge (Fig. 3) towards the main Tymphi ridge and cirques 1-4. B: Well-developed cirques on the northern slopes of Mount Tymphi. C: Large relict rock glacier ridges in the well-developed north-facing Tsouka Rossa cirques on Mount Tymphi (cirque numbers 15-18, Fig. 1 and Table 2). D: Complex karst topography on the southern slopes of Astraka (Fig. 2). [Photograph taken May 2003]. E: Glaciated limestone pavements on the southern slopes of Mount Tymphi, in valleys south of the Laccos Tselon and Megalon Litharion cirques (cirque numbers 5-7, Fig. 1 and Table 2).

cirque closure in vertical section. The variance in quantified cirque form parameters between two-sample populations, one from ophiolite terrains and one from limestone terrains, was analysed using the two-sample $t$ test (Freund, 1998, p. 313-314).

\section{Results}

Glacier characteristics on the three mountain areas during different glaciations are presented in Table 1 . During the most extensive Skamnellian Stage glaciation 
Table 2

Morphometric characteristics of the North Pindus cirques

\begin{tabular}{|c|c|c|c|c|c|c|c|c|c|c|}
\hline $\begin{array}{l}\text { Cirque } \\
\text { no. }\end{array}$ & $\begin{array}{l}\text { Cirque } \\
\text { name }\end{array}$ & $\begin{array}{l}\text { Cirque length - } \\
L[\mathrm{~m}]\end{array}$ & $\begin{array}{l}\text { Cirque width } \\
-W[\mathrm{~m}]\end{array}$ & $\begin{array}{l}\text { Cirque amplitude } \\
-A[\mathrm{~m}]\end{array}$ & $L / W$ & $W / A$ & $\begin{array}{l}\text { Plan closure } \\
{\left[0->180^{\circ}\right]}\end{array}$ & $\begin{array}{l}\text { Profile closure } \\
\left(0-90^{\circ}\right)\end{array}$ & Orientation & \\
\hline \multicolumn{11}{|c|}{ TYMPHI [limestone] } \\
\hline 1 & Catsantoni & 1850 & 1550 & 460 & 1.2 & 3.4 & 148.0 & 18.2 & $\mathrm{~S}$ & \\
\hline 2 & $\begin{array}{l}\text { Orfanoros } \\
\text { west }\end{array}$ & 750 & 625 & 240 & 1.2 & 2.6 & 110.0 & 19.3 & $\mathrm{~S}$ & \\
\hline 3 & $\begin{array}{l}\text { Orfanoros } \\
\text { east }\end{array}$ & 850 & 800 & 280 & 1.1 & 2.9 & 167.0 & 19.5 & $\mathrm{~S}$ & \\
\hline 4 & Lefcusi & 975 & 625 & 220 & 1.6 & 2.8 & 164.0 & 14.8 & S & \\
\hline 5 & $\begin{array}{l}\text { Laccos } \\
\text { Tselon }\end{array}$ & 2675 & 925 & 560 & 2.9 & 1.7 & 178.0 & 28.4 & $\mathrm{~S}$ & \\
\hline 6 & $\begin{array}{l}\text { M. Litharia } \\
1\end{array}$ & 1200 & 750 & 380 & 1.6 & 2.0 & 158.0 & 28.1 & S & \\
\hline 7 & $\begin{array}{l}\text { M. Litharia } \\
2\end{array}$ & 575 & 400 & 300 & 1.4 & 1.3 & 169.0 & 37.9 & $\mathrm{~S}$ & \\
\hline 8 & Tsioumako & 825 & 500 & 320 & 1.7 & 1.6 & 160.0 & 33.7 & W & \\
\hline 9 & Vrichos & 825 & 875 & 340 & 0.9 & 2.6 & 106.0 & 30.1 & S & \\
\hline 10 & Plaghia 2 & 550 & 375 & 200 & 1.5 & 1.9 & 75.0 & 32.2 & $\mathrm{E}$ & \\
\hline 11 & Plaghia 1 & 575 & 500 & 340 & 1.2 & 1.5 & 133.0 & 35.4 & $\mathrm{E}$ & \\
\hline 12 & Laccos & 1050 & 1000 & 600 & 1.1 & 1.7 & 216.0 & 53.1 & E & \\
\hline 13 & Dimitrios & 1025 & 825 & 540 & 1.2 & 1.5 & 246.0 & 36.0 & $\mathrm{E}$ & \\
\hline 14 & Maghoula 1 & 1250 & 660 & 550 & 1.9 & 1.2 & 151.0 & 45.0 & $\mathrm{~N}$ & \\
\hline 15 & $\begin{array}{l}\text { Tsouka } \\
\text { Rossa } 1\end{array}$ & 700 & 500 & 380 & 1.4 & 1.3 & 123.0 & 53.1 & $\mathrm{E}$ & \\
\hline 16 & $\begin{array}{l}\text { Tsouka } \\
\text { Rossa } 2\end{array}$ & 600 & 375 & 280 & 1.6 & 1.3 & 80.0 & 36.3 & $\mathrm{~N}$ & \\
\hline 17 & $\begin{array}{l}\text { Tsouka } \\
\text { Rossa } 3\end{array}$ & 450 & 525 & 380 & 0.9 & 1.4 & 90.0 & 38.3 & $\mathrm{~N}$ & \\
\hline 18 & $\begin{array}{l}\text { Tsouka } \\
\text { Rossa } 4\end{array}$ & 525 & 250 & 280 & 2.1 & 0.9 & 104.0 & 33.9 & W & \\
\hline 19 & Karteros & 1000 & 875 & 320 & 1.1 & 2.7 & 250.0 & 55.2 & $\mathrm{~N}$ & \\
\hline 20 & Kopanes 1 & 825 & 550 & 580 & 1.5 & 0.9 & 152.0 & 65.9 & E & $\mathrm{N}=7$ \\
\hline 21 & Kopanes 2 & 700 & 425 & 480 & 1.6 & 0.9 & 159.0 & 33.7 & $\mathrm{~N}$ & $\mathrm{~S}=8$ \\
\hline 22 & Gamila & 750 & 400 & 580 & 1.9 & 0.7 & 151.0 & 32.5 & $\mathrm{~N}$ & $E=6$ \\
\hline 23 & Amarandos & 675 & 750 & 500 & 0.9 & 1.5 & 171.0 & 47.2 & $\mathrm{~N}$ & $\mathrm{~W}=2$ \\
\hline & & 921.7 & 654.8 & 396.1 & $\underline{1.5}$ & $\underline{1.7}$ & 150.5 & $\underline{36.0}$ & & \\
\hline \multicolumn{11}{|c|}{ SMOLIKAS/VASILITSA [ophiolite] } \\
\hline 1 & Smolikas 1 & 700 & 425 & 240 & 1.6 & 1.8 & 148.0 & 39.6 & $\mathrm{~N}$ & \\
\hline 2 & Smolikas 2 & 800 & 550 & 540 & 1.5 & 1.0 & 114.0 & 50.9 & $\mathrm{~N}$ & \\
\hline 3 & Smolikas 3 & 350 & 325 & 180 & 1.1 & 1.8 & 129.0 & 50.9 & $\mathrm{~N}$ & \\
\hline 4 & Smolikas 4 & 575 & 675 & 180 & 0.9 & 3.8 & 108.0 & 33.7 & E & \\
\hline 5 & Moasa 1 & 750 & 1050 & 200 & 0.7 & 5.3 & 181.0 & 53.1 & $\mathrm{~N}$ & \\
\hline 6 & Moasa 2 & 650 & 800 & 240 & 0.8 & 3.3 & 164.0 & 53.1 & $\mathrm{~N}$ & \\
\hline 7 & Moasa 3 & 625 & 1250 & 200 & 0.5 & 6.3 & 86.0 & 42.1 & $\mathrm{E}$ & \\
\hline 8 & Bogdoni & 600 & 825 & 180 & 0.7 & 4.6 & 155.0 & 18.0 & $\mathrm{~S}$ & \\
\hline 9 & Samarina & 308 & 325 & 100 & 0.9 & 3.3 & 141.0 & 14.5 & $\mathrm{~N}$ & $\mathrm{~N}=8$ \\
\hline 10 & Vaslilitsa 1 & 250 & 325 & 100 & 0.8 & 3.3 & 33.0 & 20.2 & $\mathrm{~N}$ & $S=1$ \\
\hline 11 & Vasilitsa 2 & 525 & 950 & 200 & 0.6 & 4.8 & 75.0 & 14.9 & $\mathrm{E}$ & $E=3$ \\
\hline \multirow[t]{6}{*}{12} & Vasilitsa 3 & 200 & 625 & 120 & 0.3 & 5.2 & 23.0 & 21.8 & $\mathrm{~N}$ & $\mathrm{~W}=0$ \\
\hline & & $\underline{527.8}$ & 677.1 & 206.7 & 0.9 & 3.7 & 113.1 & 34.4 & & \\
\hline & $t$ & 2.66 & -0.215 & 4.82 & 3.82 & -4.95 & 2.21 & 0.323 & & \\
\hline & SD & 416 & 291 & 124 & 0.43 & 1.11 & 47.6 & 13.8 & & \\
\hline & $\begin{array}{l}\text { Degrees of } \\
\text { freedom }\end{array}$ & 33 & 33 & 33 & 33 & 33 & 33 & 33 & & \\
\hline & Probability & 0.012 & 0.83 & 0.0002 & 0.0006 & $<0.0001$ & 0.034 & 0.75 & & \\
\hline
\end{tabular}

Cirque orientation was divided into 4 directions: North $=315-045^{\circ}$; South $=135-225^{\circ}$; East $=045^{\circ}-135^{\circ}$; West $=225-315^{\circ}$. Values in bold and underlined are mean values of the cirque form data in the different massifs. 
(MIS 12), 21 glaciers covered a total area of at least $70.1 \mathrm{~km}^{2}$ on Mounts Tymphi, Smolikas and Vasilitsa with mean ELAs of 1741, 1680 and 1675 m respectively (Table 1). On limestone Mount Tymphi [2497 m a.s.1.], ice covered c. $59.3 \mathrm{~km}^{2}$ and the largest and lowest glaciers formed on the south-facing slopes where several ice fields supplied numerous outlet glaciers (Fig. 2). On north-facing slopes, glaciers were generally smaller and higher in comparison with those on the south-facing slopes.

On the ophiolite terrains of Mount Smolikas [2637 m a.s.l.] and Mount Vasilitsa [2248 m a.s.1.] glaciers covered an area of $c .11 .5 \mathrm{~km}^{2}$ during the most extensive glaciation - much less than on Mount Tymphi $\left(59.2 \mathrm{~km}^{2}\right)$, even though several summits of Mount Smolikas exceed the highest summit of Tymphi by over $100 \mathrm{~m}$ (Fig. 2). The largest glacier on Mount Smolikas formed in the Vadulakkos valley and covered an area of $7.32 \mathrm{~km}^{2}$. This valley glacier was north-facing, c. $7 \mathrm{~km}$ long and was fed by cirque glaciers on the northern side of the main Smolikas summit ridge. All other glaciers, including those on Vasilitsa, emanated from east- or northeast-facing cirques (Fig. 2).

During the Vlasian Stage (MIS 6), 21 glaciers covered a total area of $29.1 \mathrm{~km}^{2}$ on Mounts Tymphi, Smolikas and Vasilitsa with mean ELAs of 1862, 1997 and $1865 \mathrm{~m}$ a.s.l. respectively (Table 1). On Mount Tymphi, fourteen glaciers covered a total area of $21.33 \mathrm{~km}^{2}$ - about $36 \%$ of the area covered by ice during the most extensive glacial phase during the Skamnellian Stage. In some areas, such as on the south slopes of Astraka and over large parts of the Tymphi plateau (Fig. 2), no deposits relating to the Vlasian Stage can be found. This may be the result of higher ELAs during this glacial phase.

On Mount Smolikas and Mount Vasilitsa, glaciers covered an area of just $7.8 \mathrm{~km}^{2}-$ c. $37 \%$ of that on neighbouring Tymphi. Moreover, the Smolikas glaciers had a significantly higher mean ELA (1997 m a.s.l.) than the glaciers on Tymphi (mean ELA: $1862 \mathrm{~m}$ a.s.l.), unlike during the Skamnellian Stage when the mean ELA of the Smolikas glaciers was more than $60 \mathrm{~m}$ lower than that on Tymphi. On Mount Smolikas, the north-facing Vadulakkos glacier was the largest and lowest glacier, covering an area of $4.86 \mathrm{~km}^{2}$ with an ELA of $1890 \mathrm{~m}$ a.s.l. and extended c. $6.6 \mathrm{~km}$ from source to snout (Fig. 2). This glacier was only $34 \%$ smaller and $6 \%$ shorter than the Skamnellian Stage (MIS 12) glacier in the same valley, although the ELA was $190 \mathrm{~m}$ higher and similar to the Vlasian Stage mean ELA for Mount Tymphi. On Mount Vasilitsa during the Vlasian Stage, small cirque glaciers all had a northeasterly aspect and covered a combined area of only $1.21 \mathrm{~km}^{2}$.
During the Tymphian Stage (MIS 5d-2) small cirque glaciers formed in all three mountains areas with mean ELAs of 2174, 2241 and $2050 \mathrm{~m}$ a.s.l. on Tymphi, Smolikas and Vasilitsa respectively. On Mount Tymphi, 6 glaciers covered an area of c. $3.9 \mathrm{~km}^{2}$, of which 4 were north-facing and 2 south-facing. Interestingly, the southfacing glaciers were the largest and lowest of these glaciers (Table 1). In addition, 6 rock glaciers formed on Mount Tymphi, 5 in north-facing cirques and 1 on a west-facing slope (Hughes et al., 2006a) (Fig. 4C). On Mount Smolikas, five cirque glaciers covered an area of c. $2.55 \mathrm{~km}^{2}$ and all faced towards the north or north-east, whilst on Mount Vasilitsa a very small glacier occupied an area of $0.12 \mathrm{~km}^{2}$ in a north-east facing cirque.

Form data for all 35 cirques (Fig. 1) are presented in Table 2 together with the results of a two-sample $t$-test between data from limestone and ophiolite terrains. The probability values are $<0.05$ for cirque length $(L$; $p=0.012)$, cirque amplitude $(A ; p=0.0002)$, cirque length/width ratio $(L / W ; p=0.0006)$, cirque width/ amplitude ratio $(W / A ; p=<0.0001)$ and cirque plan closure $(p=0.034)$. Thus, the null hypothesis - that there is no significant difference between the ophiolite and limestone cirques for these cirque properties - can be rejected. However, probability values exceed 0.05 for cirque width $(W ; p=0.83)$ and profile closure $(p=0.75)$. Thus, for these cirque properties, the null hypothesis must be accepted - there is no significant difference in cirque width and profile closure between cirques formed in ophiolite and limestone lithologies. The limestone cirques of Mount Tymphi also had a wider range of orientations, although a majority of glaciers faced south. In contrast, on Mounts Smolikas and Vasilitsa two thirds of all cirques had northerly aspects.

Some areas display sedimentary evidence of glaciation in lower valley areas but no cirque forms in upper areas. This is the case on the northern and southern slopes of Astraka (2436 m a.s.1.) on Mount Tymphi (Fig. 2). On the northern slopes, Skamnellian and Vlasian Stage glaciers emanated from the 600 metre-high northern cliffs but did not incise a clear cirque form in these cliffs. On the southern slopes, a Skamnellian Stage plateau glacier occupied the area to the south of Astraka forming moraines in lower valleys but no cirques in the upper valley areas (Hughes et al., 2006a).

\section{Geological controls on glaciation in the Pindus Mountains}

On Mount Tymphi, glaciers had a wide of range of orientations during different Pleistocene glaciations (Table 1). During the most extensive glaciation of the 
Skamnellian Stage, glaciers were predominantly southfacing and aspect appears to have had little bearing on the overall distribution of the glaciers. Thus, factors such as shading and lee-slope accumulation appear not to have been dominant controls on glacier development during this glaciation. However, glaciers were largely north-facing during later and less extensive glaciations and, during the last glaciation (Tymphian Stage), two thirds of all glaciers had northerly aspects. Nevertheless, during the latter glaciation the largest and lowest altitude glaciers were south-facing (Table 1).

The predominantly south-facing cirques and glaciers formed in the limestones of Mount Tymphi (Table 2) are unlike the majority of cirques and glaciers worldwide, which are more often climaticallycontrolled and consequently have northern or eastern aspects (Evans, 1977, 2006). The dominance of southfacing glaciers was most pronounced during the most extensive glaciation of the Skamnellian Stage (Fig. 2). Four south-facing cirques (cirque numbers 1-4 in Fig. 1) do not contain evidence of glaciation during later cold stages, when it appears that conditions increasingly favoured north-facing glaciers. Climatic conditions during the Skamnellian Stage appear to have been severe enough to override any benefit from local controls, such as shade in north-facing cirques, enabling the largest and lowest glaciers to form on south-facing slopes (Fig. 4A). More marginal glacial conditions during later cold stages appear to have forced glaciers to occupy locally-favourable topographic settings with northern and eastern aspects (Fig. 4B,C). A similar scenario may be applicable to the Pyrenees where Pleistocene cirques have developed in all aspects (García-Ruiz et al., 2000), whereas more recent Holocene glaciers have largely been restricted to north-facing cirques (Grove, 2004; LópezMoreno et al., 2006).

The large south-facing glaciers of the Skamnellian Stage and the presence of the lowest Tymphian Stage glaciers in south-facing cirques (Table 1, Figs. 2 and 3) may be related to local variability in precipitation. For example, in the Alpes Maritimes, Federici and Spagnolo (2004) noted that the largest cirques had south-southwest aspects and suggested that this was the result of higher snowfall on these slopes. A similar scenario may be invoked to explain the dominant south-facing glaciers of Mount Tymphi, especially since the polar front is thought to have existed at $\sim 44^{\circ} \mathrm{N}$ during the last cold stage with depressions tracking west-east over Greece off the Ionian Sea (Florineth and Schlüchter, 2000). This track of depressions would have resulted in southwesterly airflows during frontal rainfall in north- west Greece followed by northwesterly winds once fronts had passed. However, given that on neighbouring ophiolite mountains nearly all glaciers formed on northand east-facing slopes (Fig. 2), geological factors are likely to have promoted south-facing glacier development on Mount Tymphi.

In limestone areas like Mount Tymphi, it is possible that snow accumulation is favoured by karstic hollows and larger-scale structural controls on topography. Furthermore, the limestone bedrock of Mount Tymphi is also well-jointed and more prone to frost shattering than the massive ophiolites of Mounts Smolikas and Vasilitsa (Fig. 4D), and would have supplied greater amounts of debris to former glacier surfaces, thus inhibiting ablation ( $c f$. Nakawo and Young, 1981, 1982) and enabling large glaciers to form on south-facing slopes. Structural geology is particularly important since the northern slopes of Mount Tymphi are characterised by a steep, faulted escarpment (Fig. 4B), whilst the southern slopes are relatively gentle in comparison (Fig. 4E), resulting in ample accommodation space. Importantly, these relatively gentle southern slopes promote karstic hollows for snow accumulation. It is likely, therefore, that a karstic landscape played a key role in glacier development, as has been noted elsewhere in the Mediterranean, such as in the Picos de Europa of Spain (Smart, 1986) and the Algerian Djurdjura (Barbier and Cailleux, 1950). Irregularities in karstic topography are particularly important for enhancing localised snow accumulation, since features such as dolines act as traps for windblown snow (Hughes et al., 2006d). Consequently, snow fields can achieve considerable depths in karstic terrain compared with other non-karst terrains, contributing to more rapid glacier inception.

The relationship between karst development and glaciation is likely to have been two-way, with preexisting karst influencing glacier development and glaciation influencing karstic forms. This interaction was summarised by Ford (1979) who distinguished between karsti-glacial and glacio-karstic landforms, the former being glacial forms modified by karst processes and the latter karst forms modified by glacial processes. Glacio-karst landforms are the result of glacial erosion, such as plucking of karst forms (e.g. Ford and Williams, 1989; Fig. 10.7, p. 480), and also ample availability of cold meltwater during glaciation. For example, on Mount Tymphi, deeply jointed limestone pavements display evidence of plucking and abrasion (Fig. 4E), whilst doline fields are frequently concentrated at the margins of former glaciers reflecting proglacial meltwater discharge. The latter feature was first noted on the southern slopes of Mount Tymphi by Waltham (1978). 

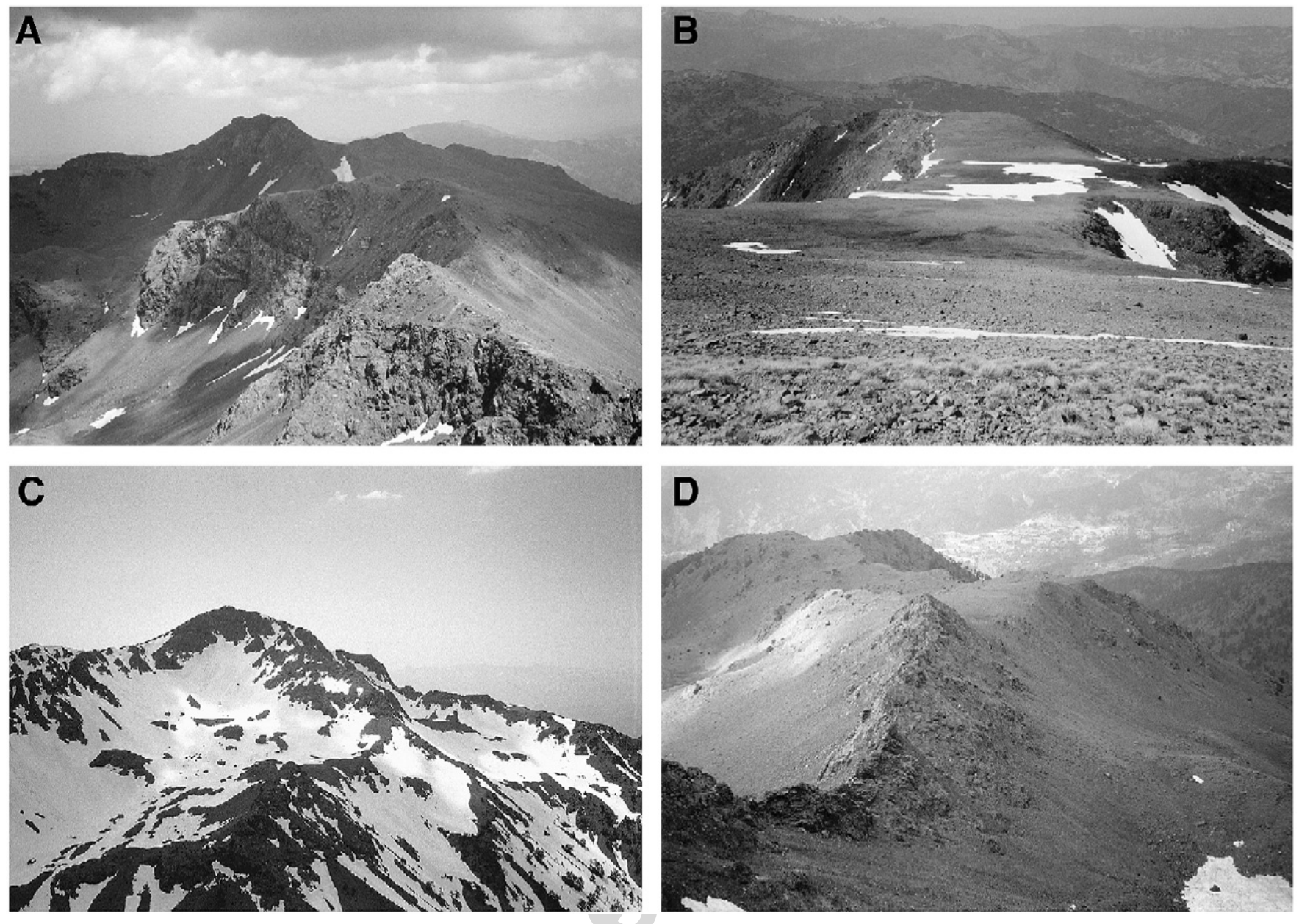

Fig. 5. A: Looking east from the highest summit of Mount Smolikas (2637 m a.s.1.) towards the eastern summit known as Moasa (2610 m a.s.1.) (refer to Figs. 1 and 2). Glaciers formed only on the northern side of this ridge (left side) in cirque number 5 leaving the southern slopes unglaciated, in contrast with Mount Tymphi (Fig. 2). B: A plateau surface bounded by cirques on Mount Smolikas (left side: Moasa 1, cirque number 5; right side: Moasa 2, cirque number 6 - refer to Fig. 1 and Table 2). This topography would have favoured windblown snow accumulation in lee-side cirques. C: Looking southwest towards the summit of Smolikas (2637 $\mathrm{m}$ a.s.1.) and cirque number 4 (Fig. 1). This cirque is characteristic of the ophiolite cirques with a low $L / W$ ratio and a high $W / A$ ratio. D: An arête separating two north-facing cirques (Smolikas 1 and Smolikas 3 (cirques 1 and 3 in Fig. 1) on Mount Smolikas. Unlike on limestone Mount Tymphi (Fig. 4), slopes on ophiolite are more subdued and glacial features such as arêtes and cirque backwalls do not attain such great heights. However, the presence of steep, but limited amplitude, cirque backwalls (Fig. 5A) may explain why there is only a small difference between cirque profile values on the limestone and ophiolite mountains.

The deepest known cave in Greece occurs in this area the Epos chasm, $442 \mathrm{~m}$ deep - and deep caverns abound with the Provetina, Tripa Tis Nifis and Tsepelovo Spiara reaching depths of 389,299 and $228 \mathrm{~m}$ respectively (Waltham, 1978).

The limited glaciation on Mount Smolikas is surprising given that the altitude of this mountain is second only in Greece to Mount Olympus (2912 m a.s.l.), a limestone mountain which was extensively glaciated during the Pleistocene (Smith et al., 1997). Furthermore, in contrast to Mount Tymphi, glaciers predominantly emanated from north- and east-facing cirques during all three recorded glaciations on ophiolite Mounts Smolikas and Vasilitsa (Tables 1 and 2) (Fig. 5A). Thus, it is likely that aspect was the dominant local control on glacier development. All the cirques are bounded to the west by high convex ridges and plateau surfaces (Fig. 5B) and wind-blown snow accumulation may have also exerted some control on glacier distribution, especially given that precipitation-bearing atmospheric depression systems would have arrived from the west, off the Ionian Sea. Whilst the distribution of Pleistocene glaciers in ophiolite areas appears to have been controlled by local topographic ablative and accumulative controls, this did not inhibit the development of lower glaciers than in neighbouring limestone areas. However, during later glaciations, glaciers in ophiolite areas were higher than those in limestone areas. Higher ELAs during the last two major glaciations on both Mount Smolikas and Mount Vasilitsa may reflect lower 
precipitation than on Mount Tymphi since precipitation is today lower on Mount Smolikas than on Mount Tymphi due to its slightly more inland position. However, given that Mount Smolikas is $130 \mathrm{~m}$ higher than Mount Tymphi (2497 m a.s.1.) and is characterised by a much larger area of high ground above $2000 \mathrm{~m}$ a.s.1., the restricted extent of the Smolikas glaciers must be the result of additional factors other than lower precipitation.

Lithological factors influencing local topography and rock colour may explain the restricted size and distribution of all the Pleistocene glaciers and the restricted altitudes of Vlasian and Tymphian Stage glaciers on Mounts Smolikas and Vasilitsa. Firstly, unlike limestone, ophiolite is impermeable and erodes to form relatively smooth slope surface profiles (Fig. 5C, D), thus reducing locally-favourable sites for snow accumulation. Secondly, the dark ophiolite bedrock and debris surrounding and covering areas of snow and ice would have promoted greater rates of ablation compared to snow and ice surfaces covered by much palercoloured limestone debris. It is well established that albedo is directly related to surface colour (Geiger, $1965)$ and the importance of glacier albedo in controlling glacier melt has been noted on modern glaciers in the Alps (Paul et al., 2005).

The differences in quantified characteristics between ophiolite and limestone cirques may help explain variations in Pleistocene glacier distribution in the Pindus Mountains. There was no significant difference in quantified values describing cirque width and profile closure between cirques formed in ophiolite and limestone. However, there was a significant difference between cirque length, cirque amplitude, length/width and width/amplitude ratios and also plan closure between ophiolite and limestone cirques. The data (Table 2) shows that cirque basins formed in limestone are significantly longer, deeper and more enclosed than those formed in ophiolite and indicates concentrated glacial incision in limestone areas (compare Fig. 4B with Fig. 5A and C).

Variations in rock hardness, jointing and bedding are known to have a major influence on the effectiveness of glacial erosion (Haynes, 1968; Evans, 1994). The fact that limestone cirques are narrower, deeper and consequently more enclosed than ophiolite cirques may be the result of subglacial plucking exploiting widespread jointing and subglacial bedrock weaknesses promoted by subterranean karstic drainage, as noted earlier (Ford and Williams, 1989) (Fig. 4E). Neither of these characteristics applies to the ophiolite of Mount Smolikas and Vasilitsa, which is massive and impermeable.
The contrast in glacier distribution and cirque development between nearby glaciated limestone and ophiolite areas highlights the role of non-climatic controls, such as lithology and geological structure, on the evolution of glaciated terrains. However, several other studies have found a weak or non-existent relationship between geology and cirque form (e.g. Embleton and Hamann, 1988; Evans, 1994; Evans and Cox, 1995). This may be because no comparison has ever been made between cirques formed in ophiolite and limestone rocks, which may be unique in exhibiting clear differences in cirque development and glacier formation. Alternatively, it may be because other studies have compared areas which have been covered by ice sheets on multiple occasions, with cirques only locallyglaciated during both the early and later stages of glaciation (e.g. Evans, 1999). Cirque development in these areas is likely to be a polygenetic signal of a complex glacial history.

Elsewhere in the Mediterranean, García-Ruiz et al. (2000) found some evidence to suggest that lithology was an important control on cirque development in the Pyrenees. However, the role of lithology was less obvious than altitude, which was identified as the most important factor. This again, is symptomatic of widespread topographic submergence by regional ice cover on multiple occasions. In contrast, mountains only ever locally-glaciated during the Pleistocene, such as those in Greece, may exhibit a simpler cirque evolutionary history.

The results of this study suggest that limestone mountain areas across the Eastern Mediterranean would have been foci of significant glacier expansion during Pleistocene cold stages. This may be important towards understanding the glacier distribution and development in areas such as the Balkans and Turkey where limestone and ophiolite areas form many of the highest massifs. Different lithologies clearly exert varying degrees of control on glacier formation and cirque development. Further research in areas such as the high glaciated granite and metamorphic massifs of Bulgaria, Corsica and Morocco will help further elucidate the role of geology on Pleistocene glaciation in the Mediterranean mountains.

\section{Conclusions}

1. During the most extensive Middle Pleistocene glaciation in Greece (MIS 12), glaciers in limestone areas had a wide range of distributions and the largest glaciers developed on south-facing slopes. In contrast, in ophiolite areas, glaciers had north- and 
east-facing aspects. During later glaciations (MIS 6 and $5 \mathrm{~d}-2$ ), under climatic conditions more marginal to glacier formation, aspect appears to have become more important in limestone areas. However, even during the last major glaciation, the lowest glaciers that formed on limestone terrains were south-facing.

2. In limestone areas, cirques display a wide range of aspects in contrast to the near total dominance of north-facing cirques in ophiolite areas. Furthermore, cirques in limestone areas are deeper, longer and more enclosed cirques than cirques formed in ophiolite bedrock.

3. Contrasts in both the distribution of glaciation and cirque development between neighbouring limestone and ophiolite mountains can be related to geological rather than climatic controls. Widespread jointing and well-developed karst provide local topographic complexity and promote subglacial bedrock incision. These findings highlight the important role of geology (lithology and geological structure) on glaciation in limestone and ophiolite massifs, both of which characterise some of the highest mountains of the Eastern Mediterranean.

\section{Acknowledgements}

PDH was funded by a University of Cambridge Domestic Research Studentship and a University of Manchester Faculty of Humanities Fellowship. We would like to thank the Institute of Geology and Mineral Exploration for permission to work in Greece and Dr. Charles Turner, University of Cambridge, for the loan of geological maps for these areas.

\section{References}

Barbier, A., Cailleux, A., 1950. Glaciare et périglaciaire dans le Djurdjura occidental (Algérie). Comptes Rendus des Séances de l'Académie des Sciences, Paris 365-366 (Juillet-Décembre).

Bennett, M., 1990. The cwms of Snowdonia: a morphometric analysis. Research paper, vol. 2. Department of Geography, Queen Mary and Westfield College, London.

Embleton, C., Hamann, C., 1988. A comparison of cirque forms between the Austrian Alps and the Highlands of Britain. Zeitschrift für Geomorphologie N.F. Suppl. 70, 75-93.

Evans, I.S., 1969. The geomorphology of glacial and nival areas. In: Chorley, R.J. (Ed.), Water, earth and Man. Methuen, London, pp. $369-380$.

Evans, I.S., 1977. World-wide variations in the direction and concentration of cirque and glacier aspects. Geografiska Annaler 59A, $151-175$.

Evans, I.S., 1994. Lithological and structural effects on forms of glacial erosion: cirques and lake basins. In: Robinson, D.A., Williams, R.B.G. (Eds.), Rock Weathering and Landform Evolution. John Wiley \& Sons, pp. 455-472.
Evans, I.S., 1999. Was the cirque glaciation of Wales timetransgressive, or not? Annals of Glaciology 28, 33-39.

Evans, I.S., 2006. Local aspect asymmetry of mountain glaciation: a global survey of consistency of favoured directions for glacier numbers and altitudes. Geomorphology 73, 166-184.

Evans, I.S., Cox, N.J., 1995. The form of glacial cirques in the English Lake District. Zeitschrift für Geomorphologie N.F. 39, 175-202.

Federici, P.R., Spagnolo, M., 2004. Morphometric analysis on the size, shape and areal distribution of glacial cirques in the Maritime Alps (Western French-Italian Alps). Geografiska Annaler 86A, 235-248.

Ford, D.C., 1979. A review of Alpine karst in the Southern Rocky Mountains of Canada. Bulletin of the National Speleogical Society $41,53-65$.

Ford, D.C., Williams, P.W., 1989. Karst Geomorphology and Hydrology. Unwin Hyman, London. 601 pp.

Florineth, D., Schlüchter, C., 2000. Alpine evidence for atmospheric circulation patterns in Europe during the last glacial maximum. Quaternary Research 54, 295-308.

Freund, J.E., 1998. Modern Elementary Statistics. Prentice Hall, London. 574 pp.

García-Ruiz, J.M., Gómez-Villar, A., Ortigosa, L., Martí-Bono, C., 2000. Morphometery of glacial cirques in the central Spanish Pyrenees. Geografiska Annaler 82A, 433-442.

Geiger, R., 1965. The Climate Near the Ground. Harvard University Press. $611 \mathrm{pp}$.

Grove, J., 2004. Little Ice Ages: Ancient and Modern, vol. I and II. Routledge, London. 718 pp.

Haynes, V.M., 1968. The influence of glacial erosion and rock structure on corries in Scotland. Geografiska Annaler 50A, 221-234.

Hughes, P.D., Woodward, J.C., Gibbard, P.L., 2006a. Late Pleistocene glaciers and climate in the Mediterranean region. Global and Planetary Change 46, 83-98.

Hughes, P.D., Woodward, J.C., Gibbard, P.L., Macklin, M.G., Gilmour, M.A., Smith, G.R., 2006b. The glacial history of the Pindus Mountains, Greece. Journal of Geology 114, 413-434.

Hughes, P.D., Woodward, J.C., Gibbard, P.L., 2006c. The last glaciers of Greece. Zeitschrift für Geomorphologie 50, 37-61.

Hughes, P.D., Woodward, J.C., Gibbard, P.L., 2006d. Quaternary glacial history of the Mediterranean mountains. Progress in Physical Geography 30, 334-364.

Hughes, P.D., Woodward, J.C., Gibbard, P.L., in press. Middle Pleistocene cold stage climates in the Mediterranean: new evidence from the glacial record. Earth and Planetary Science Letter. doi:10.1016/j.epsl.2006.10.019.

IGME (Institute of Geology and Mineral Exploration), 1970. 1:50,000 Geological map of Greece. Tsepelovon Sheet. Institute of Geological and Mineral Exploration, Athens.

IGME (Institute of Geology and Mineral Exploration), 1987. 1:50,000 Geological map of Greece. Konitsa Sheet. Institute of Geological and Mineral Exploration, Athens.

Jones, G., Robertson, A.H.F., 1997. Tectono-stratigraphy and evolution of the Mezozoic Pindus ophiolite and related units, northwestern Greece. Journal of the Geological Society, London 148, 267-288.

King, G., Sturdy, D., Bailey, G., 1997. The tectonic background to the Epirus Landscape. In: Bailey, G.N. (Ed.), Klithi: Palaeolithic settlement and Quaternary landscapes in northwest Greece. Klithi in its local and regional setting, vol. 2. MacDonald Institute for Archaeological Research, Cambridge, pp. 541-558.

López-Moreno, J.I., Nogués-Bravo, D., Chueca-Cía, J., Julián-Andrés, A., 2006. Glacier development and topographic context. Earth Surface Processes and Landforms 31, 1585-1594. 
Nakawo, M., Young, G.J., 1981. Field experiments to determine the effect of a debris layer on ablation of glacier ice. Annals of Glaciology 2, 85-91.

Nakawo, M., Young, G.J., 1982. Estimate of glacier ablation under debris layer from surface temperature and meteorological variables. Journal of Glaciology 28, 29-34.

Paul, F., Machguth, H., Kääb, A., 2005. On the impact of glacier albedo under conditions of extreme glacier melt: the summer of 2003 in the Alps. EARSeL eProceedings, vol. 4, pp. 139-149.

Robertson, A., Shallo, M., 2000. Mesozoic-Tertiary tectonic evolution of Albania in its regional Eastern Mediterranean context. Tectonophysics 316, 197-254.
Sfikas, G., 1979. The Mountains of Greece. Efstathiadis Group. $204 \mathrm{pp}$.

Smart, P.L., 1986. Origin and development of glacio-karst closed depressions in the Picos de Europa, Spain. Zeitschrift für Geomorphologie NF 30, 423-443.

Smith, G.W., Nance, R.D., Genes, A.N., 1997. Quaternary glacial history of Mount Olympus, Greece. Geological Society of America Bulletin 109, 809-824.

Waltham, A.C., 1978. The caves and karst of Astraka, Greece. Transactions of the British Cave Research Association 5, 1-12. 